\title{
Surveillance for Zoonotic Vector-Borne Infections Using Sick Dogs from Southeastern Brazil
}

\author{
PEDRO PAULO VISSOTTO DE PAIVA DINIZ, ${ }^{1}$ DENISE SARETTA SCHWARTZ, ${ }^{2}$ \\ HELIO SILVA AUTRAN DE MORAIS, ${ }^{3}$ and EDWARD BEALMEAR BREITSCHWERDT ${ }^{1}$
}

\begin{abstract}
For many vector-borne organisms, dogs can be used as sentinels to estimate the risk of human infection. The objective of this study was to use dogs as sentinels for multiple vector-borne organisms in order to evaluate the potential for human infection with these agents in southeastern Brazil. Blood from 198 sick dogs with clinicopathological abnormalities consistent with tick-borne infections were selected at the São Paulo State University Veterinary Teaching Hospital in Botucatu and tested for DNA and/or antibodies against specific vector-borne pathogens. At least one organism was detected in $88 \%$ of the dogs, and Ehrlichia canis DNA was amplified from $78 \%$ of the blood samples. Bartonella spp. seroreactivity was found in $3.6 \%$. Leishmania chagasi antibodies were detected in $1 \%$ of the dogs. There was no serological or polymerase chain reaction evidence of infection with Anaplasma phagocytophilum, Borrelia burgdorferi, Ehrlichia chaffeensis, Ehrlichia ewingii, and Rickettsia rickettsii. The full E. canis 16S rRNA gene sequence of one of the Brazilian strains obtained in this study was identical to the causative agent of human ehrlichiosis in Venezuela. Ehrlichia canis may pose a human health hazard and may be undiagnosed in southeastern Brazil, whereas exposure to the other organisms examined in this study is presumably infrequent. Key Words: Tick-borne infections-Dog-Ehrlichia canis-Bartonella henselae-Bartonella vinsonii subsp. berkhoffii-Epidemiology—Sentinel-PCR.
\end{abstract}

\section{INTRODUCTION}

$\mathbf{I}_{\mathrm{h}}^{\mathrm{N}}$ N RECENT DECADES, the Brazilian government has faced many challenges related to control and prevention of infectious diseases in humans and animals. Ecological diversity, in association with substantial economic and social discrepancies, has made the control and eradication of vector-borne diseases, such as human bartonellosis, Brazilian spotted fever, ehrlichiosis, leishmaniasis, and Lyme disease, an ongoing challenge to the public health infrastructure (Calic et al. 2004, Horta et al. 2004, da
Costa et al. 2005, Ministério da Saúde do Brasil 2007).

Animals have been used as sentinels for the detection of environmental hazards and infectious disease transmission, as well as indicators of bioterrorism events (Backer et al. 2001, Duncan et al. 2004, Rabinowitz et al. 2006). With estimates that $75 \%$ of the recently discovered emerging infectious diseases are zoonotic in nature (Taylor et al. 2001), studies involving pets and other animals can complement human epidemiologic studies. Because pets live in very close proximity to their owners, vector-borne

\footnotetext{
${ }^{1}$ Intracellular Pathogens Research Laboratory, Center for Comparative Medicine and Translational Research, College of Veterinary Medicine, North Carolina State University, Raleigh, North Carolina.

${ }^{2}$ School of Veterinary Medicine and Animal Science, São Paulo State University (FMVZ-UNESP), Botucatu, São Paulo, Brazil.

${ }^{3}$ School of Veterinary Medicine, University of Wisconsin, Madison, Wisconsin.

This study was presented in part at the 20th meeting of the American Society of Rickettsiology, in Pacific Grove, California, September 2006.
} 
disease data generated in pets can often provide unique information regarding incidence, risk factors and sources of exposure before the occurrence of human disease outbreaks.

Dogs are susceptible to a large number of emerging or re-emerging human vector-borne infections. As a sentinel animal, dogs are more frequently exposed to infected ticks, fleas, mosquitoes, and sand flies. In addition, dogs develop a strong organism-specific antibody response to many vector-borne pathogens, and they develop acute, and at times chronic clinical signs of illness that are very similar to disease manifestations reported in people (Lindenmayer et al. 1991). Moreover, dogs are generally accessible for safe handling and sample collection (Cleaveland et al. 2006).

The present investigation describes the first survey to use dogs as sentinels for multiple vector-borne organisms in order to evaluate the potential for human infection with these agents in southeastern Brazil. Based upon dog surveillance data, human exposure to the majority of the vector-borne infections tested in this study is likely infrequent or non-existent. However, people residing in urban areas of Brazil are exposed to Ehrlichia canis, an organism for which dogs are the primary reservoir for tick transmission of this zoonotic pathogen.

\section{METHODS}

Patients and selection criteria

This study was approved by the Medical Ethics and Animal Care Committee of São Paulo State University, College of Veterinary Medicine and Animal Science (FMVZ-Unesp). Between October 2002 and November 2003, 198 sick dogs from a population of 9,701 new dog accessions were prospectively selected at a Veterinary Teaching Hospital (VTH) of FMVZ-Unesp in Botucatu, Southeast Brazil. Dogs included in this study had at least three of the following clinical or laboratory criteria: presence of tick infestation at the time of examination, bleeding, neurological signs, inflammatory ocular disease, fever (rectal temperature $\left.>39.4^{\circ} \mathrm{C}\left[102.9^{\circ} \mathrm{F}\right]\right)$, anemia $(\mathrm{PCV}<35 \%)$, leukopenia (WBC $<6,000$ cells $/ \mu \mathrm{L}$ ), thrombocy- topenia (platelets $<150,000$ cells $/ \mu \mathrm{L}$ ) or hyperproteinemia $(\mathrm{TP}<7.8 \mathrm{~g} / \mathrm{dL})$. Dogs treated with tetracycline or imidocarb diproprionate up to 30 days before examination were excluded.

\section{Study area}

Botucatu is situated at $22^{\circ} 53^{\prime} \mathrm{S}$ and $48^{\circ} 26^{\prime} \mathrm{W}$, $225 \mathrm{~km}$ (140 miles) from the Atlantic Ocean and $804 \mathrm{~m}(2637 \mathrm{ft})$ above sea level. The county surface area is $1,482,874 \mathrm{~km}^{2}$ with an estimated population of 119,298 inhabitants in 2005, with $23.5 \%$ of inhabitants living in the rural areas and $76.5 \%$ in urban centers. The climate is typically temperate, with annual average temperature of $20.3 \pm 7.1^{\circ} \mathrm{C}$, average humidity of $74.9 \pm 21.7 \%$, and annual rainfall of $1300 \mathrm{~mm}$ (Cunha and Martins 2004). Based on the procurement of vaccines for the annual rabies control program, the estimated canine population in Botucatu in 2003 was 21,692 dogs.

\section{Serology-based assays}

A microimmunofluorescence assay (IFA) was used to test canine sera for antibodies against Bartonella vinsonii subsp. berkhoffii (isolate 93-CO-1), Bartonella henselae (strain Houston 1), Leishmania chagasi, and Rickettsia rickettsii, as described previously (Kordick et al. 1999, Oliveira 2004, Solano-Gallego et al. 2006). An ELISA-based test kit (SNAP ${ }^{\circledR} 4 \mathrm{Dx}$, IDEXX Laboratories, Inc., Westbrook, ME, USA) was used according to the manufacturer's instructions to detect Ehrlichia canis and Borrelia burgdorferi antibodies, as well as antigens of Dirofilaria immitis from dog serum. One dog was not tested by IFA and ELISA because of insufficient serum.

\section{DNA amplification-based assays}

DNA was extracted from $300 \mu \mathrm{L}$ of each dog's frozen ethylenediaminetetra-acetic acid (EDTA)-blood pellet using a commercially available kit (GFX ${ }^{\circledR}$ Genomic Blood DNA Purification, Amersham Biosciences, Piscataway, NJ, USA). The absence of polymerase chain reaction (PCR) inhibitors was demonstrated by the amplification of a fragment of the GAPDH gene (Birkenheuer et al. 2003). Rickettsia spot- 
ted-fever species were screened by real-time PCR, targeting the OmpA gene (Solano-Gallego et al., 2006). Conventional PCR was used for the amplification of $16 \mathrm{~S}$ rRNA gene of Anaplasma and Ehrlichia species (Breitschwerdt et al. 1998, Kordick et al. 1999) and 16S-23S rRNA gene intergenic transcribed spacer (ITS) of Bartonella species (Maggi and Breitschwerdt 2005).

\section{Cloning and sequencing}

To confirm the species and strains detected by PCR, amplicons from two Bartonella PCRpositive samples and 15 Ehrlichia PCR-positive samples were cloned into the plasmid pGEM$\mathrm{T}^{\circledR}$ Easy Vector System (Promega, Madison, WI, USA) and sequenced by Davis Sequencing (Davis, CA, USA). For genetic characterization, two complete sequences of $16 \mathrm{~S}$ rRNA from $E$. canis infected dogs were generated based upon sequencing of five individual clones. Chromatogram evaluation and sequence alignment were performed using ContigExpress ${ }^{\circledR}$ and Align $X^{\circledR}$ softwares (Vector $\mathrm{NTI}^{\circledR}$, version 10.1, Invitrogen Corp., Carlsbad, CA, USA). The bacterial species and strain was defined by com- paring similarities with other sequences deposited in the GenBank database up until September 2007 using the BLAST ${ }^{\circledR}$ tool version 2.0 (Altschul et al. 1990).

\section{Statistical analysis}

The agreement between PCR and IFA results was tested using the McNemar test with Yates correction for continuity using SigmaStat ${ }^{\circledR}$ statistical software (Systat Software Inc., Richmond, CA, USA). Alpha was set at 0.05.

\section{RESULTS}

\section{Study population}

We sampled dogs from 21 different cities within a range of $<5-270 \mathrm{~km} \quad(<3.1-167.8$ miles) from the São Paulo State University Veterinary Teaching Hospital (VTH), all within the state of São Paulo (Fig. 1). Ninety-one percent of the dogs came from a $45 \mathrm{~km}$ (28 miles) radius, with $75 \%$ of the dogs being from Botucatu; 98\% were from urban areas. Dogs from rural areas were under-represented in this

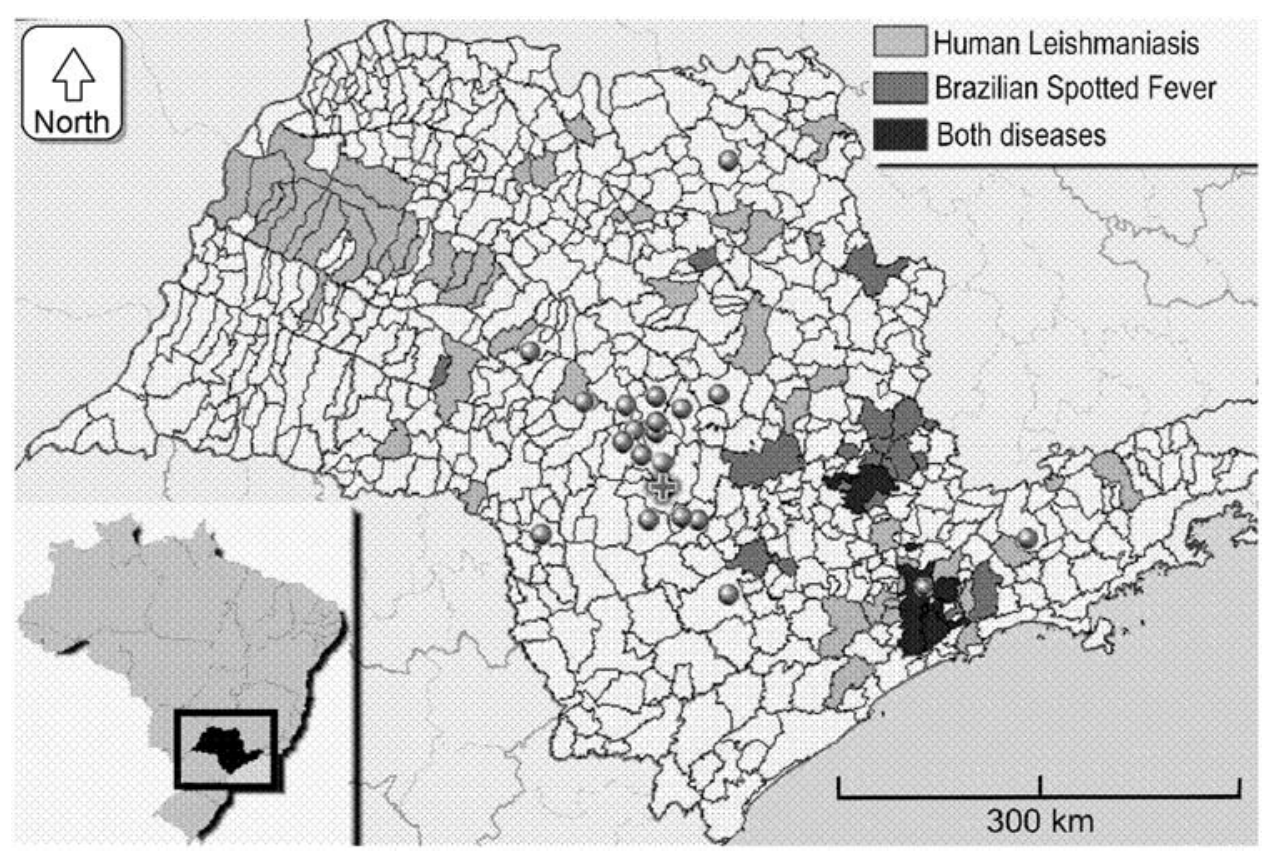

FIG. 1. Distribution of the 21 cities enrolled in this study from São Paulo state and the areas of reported human cases of Visceral Leishmaniasis and/or Brazilian Spotted Fever from the same years in which samples were collected for this study (2002/2003). The cross near the center of the map represents the location of the Veterinary Teaching Hospital. 
Table 1. Polymerase Chain Reaction (PCR) and Microimmunofluorescence

Assay (IFA) SEROlogy Results for EHRLICHIA CANIS, BARTONELLA HENSELAE, BARTONELLA VINSONII SUBSP. BERKHOFFII, AND LEISHMANIA CHAGASI From 198 Sick Dogs from São Paulo State, Brazil

\begin{tabular}{|c|c|c|c|c|}
\hline \multirow[b]{2}{*}{ Organisms(s) } & \multicolumn{2}{|c|}{$P C R+$} & \multicolumn{2}{|c|}{ IFA Seroreactive } \\
\hline & $\mathrm{N}$ & $\%$ & $\mathrm{~N}$ & $\%$ \\
\hline Ehrlichia canis & 152 & 76.8 & 138 & 70.1 \\
\hline E. canis + Bartonella henselae & 1 & 0.5 & 2 & 1.0 \\
\hline E. canis $+B$. vinsonii subsp berkhoffii & 0 & 0.0 & 3 & 1.5 \\
\hline E. canis $+B$. henselae $+B$. vinsonii & 1 & 0.5 & 0 & 0.0 \\
\hline E. canis + Leishmania chagasi & - & - & 2 & 1.0 \\
\hline B. henselae & 0 & 0.0 & 2 & 1.0 \\
\hline Negative test results & 44 & 22.2 & 50 & 25.4 \\
\hline Total & 198 & 100 & $197^{a}$ & 100 \\
\hline
\end{tabular}

${ }^{\mathrm{a} O n e}$ dog was not tested because of an inadequate sample volume.

study, with only four ( $2 \%)$ animals from four different locations included. The dog population consisted of 121 males and 77 females, with a mean weight of $17 \mathrm{~kg}$ (range, $1.8-44.5 \mathrm{~kg}$ ). One hundred and twenty dogs were pure-bred, whereas 78 were of mixed breed. Twenty-five different breeds were enrolled, with a predominance of Poodles (25/198), Boxers (15/198), Doberman Pinschers (10/198), and Rottweillers (9/198). Eight dogs were younger than 4 months of age, 26 dogs were from 4 to 12 months old, and 164 dogs were 1 year old or older.

\section{Molecular and serological prevalence}

A summary of the results is presented in Table 1. A total of 125 dogs had E. canis antibodies, and were PCR positive; 20 dogs were E. canis seropositive (PCR negative), and 28 dogs were PCR positive (seronegative). There was no difference in the E. canis frequency between PCR and IFA results ( $p=0.312)$. By PCR testing, all four rural dogs were infected with E. canis, and three of them were E. canis seroreactive. The E. canis seronegative rural dog was $B$. henselae seroreactive (titer 1:2048). DNA from A. phagocytophilum, E. chaffeensis, E. ewingii, and $R$. rickettsii DNA was not amplified from any dog blood sample. Borrelia burgdorferi, R. rickettsii antibodies, and D. immitis antigens were not detected in any serum sample. When serology and PCR results were combined, only 24 dogs $(12 \%)$ were negative by both testing modalities for all of the organisms studied.

Serology, PCR, and Bartonella strain charac- terization were reported previously (Diniz et al. 2007), without details relative to polymicrobial infection. Bartonella henselae seroreactivity was found in $2 \%(4 / 197)$ of the samples, whereas $B$. vinsonii subsp. berkhoffii antibodies were found in $1.5 \%(3 / 197)$ of the samples. Bartonella henselae DNA was amplified from only two dogs, both of which were co-infected with E. canis. One of these dogs was also co-infected with B. vinsonii subsp. berkhoffii (Diniz et al. 2007). Leishmania chagasi seroreactivity was detected in two dogs, both of which were co-infected with E. canis by PCR and serology.

All 19 PCR products, cloned and sequenced as a component of this study, confirmed the specificity of each PCR assay in all instances. Two complete E. canis $16 \mathrm{~S}$ rRNA gene sequences $(1,434 \mathrm{bp})$ were deposited in the GenBank database as strains Brazil-CO-1 (EF195134) and Brazil-CO-2 (EF195135) (from canine origin). Following comparative alignment with other Ehrlichia sequences (Table 2), E. canis strain Brazil-CO-2 was unique, whereas the Brazil-CO1 sequence was identical to E. canis strains isolated from cases of human Venezuelan ehrlichiosis (Perez et al. 1996, 2006) and two canine origin strains deposited from Greece.

\section{DISCUSSION}

Both pet and stray dogs are ubiquitous in urban areas of southeastern Brazil. The dog population has been estimated at one dog for each 3.5 to 5 people (Dias et al. 2004), which is higher 
Table 2. Ehrlichia canis 16s rRNA Gene Nucleotide Differences for IsOlates SeQuenced in This Study (CO-1 and CO-2) as Compared to Other Strains from Dogs AND Humans Deposited in GenBank Database (September, 2007)

\begin{tabular}{|c|c|c|c|c|c|c|c|c|c|c|c|c|c|}
\hline \multirow[b]{2}{*}{ Strain/Country } & \multicolumn{12}{|c|}{ Nucleotide difference at position ${ }^{\mathrm{a}}$} & \multirow{2}{*}{$\begin{array}{c}\text { Accession } \\
\text { number }\end{array}$} \\
\hline & 199 & 386 & 660 & 849 & 876 & 883 & 994 & 981 & 1014 & 1240 & 1266 & 1309 & \\
\hline Jake/USA ${ }^{b}$ & G & G & A & A & $\mathrm{A}$ & G & $\mathrm{C}$ & A & $\mathrm{T}$ & $\mathrm{T}$ & C & G & СР000107 \\
\hline CO-1/Brazil b & - & - & - & - & - & • & - & - & - & - & - & $\bullet$ & EF195134 \\
\hline TW1/Thailand ${ }^{b}$ & - & - & - & - & - & - & - & - & - & - & - & - & EU106856 \\
\hline VHE/Venezuelac & - & - & - & - & - & - & - & - & - & - & - & - & AF373612 \\
\hline VDE/Venezuelab & - & - & - & - & - & - & - & - & - & - & - & - & AF373613 \\
\hline GR21/Greece ${ }^{b}$ & - & - & - & - & - & - & - & - & - & - & - & - & EF011110 \\
\hline CO-2/Brazil ${ }^{b}$ & - & - & - & - & - & - & $\mathrm{T}$ & - & - & - & - & - & EF195135 \\
\hline Oklahoma/USA ${ }^{\mathrm{b}}$ & A & - & - & - & - & - & - & - & - & - & - & - & M73221 \\
\hline Kagoshima $1 /$ Japan $^{\mathrm{b}}$ & - & - & - & - & - & - & - & C & - & - & - & - & AF536827 \\
\hline Gzh982/Chinab ${ }^{\mathrm{s}}$ & - & - & - & - & - & - & - & - & - & $\mathrm{T}$ & - & - & AF162860 \\
\hline 611/Israe & - & $\mathrm{S}$ & - & - & - & - & - & C & - & - & - & A & U26740 \\
\hline Florida/USA ${ }^{\mathrm{b}}$ & A & - & - & - & - & - & $\bullet$ & $\bullet$ & - & - & $\mathrm{T}$ & $\bullet$ & M73226 \\
\hline PDE/Perub & - & - & G & - & - & - & $\mathrm{T}$ & - & C & - & - & - & DQ915970 \\
\hline
\end{tabular}

aThe number represents the nucleotide position of the of E. canis strain Jake; $\bullet$, same base as E. canis strain Jake; -, deletion.

bIsolate obtained from a human.

'Isolate or sequence obtained from a dog.

Sequences shorter than 1300 bp or containing degenerate oligonucleotides $(\mathrm{N})$ were excluded from the alignment.

than the suggested ratio of 1:10 proposed by the World Health Organization to minimize anthropozoonosis (Bögel 1987). Dogs can be infected naturally or experimentally with many of the same tick-borne pathogens that infect people. Therefore, surveillance using dogs as a "biomarker" or "bioaccumulator" of pathogen exposure provides public health officials an effective tool for establishing the risk of human exposure. Our results indicate a potential risk for human exposure to E. canis in urban areas in southeastern Brazil; whereas, exposure to several other vector-borne pathogens is low to nonexistent.

In 1996, the first human isolate of E. canis was obtained from the blood of a non-immunocompromised, asymptomatic veterinarian in Venezuela (Perez et al. 1996). Recently, the same E. canis strain (Venezuelan Human Ehrlichiosis-VHE) was detected in six Venezuelan patients with symptoms consistent with human monocytic ehrlichiosis (Perez et al. 2006). Ehrlichia canis is primarily transmitted to dogs by the Rhipicephalus sanguineus, the most common tick found in urban areas in Brazil. R. sanguineus parasitizes humans in Brazil (DantasTorres et al. 2006), and a recent study from southern Brazil identified $98 \%$ of ticks removed from dogs as $R$. sanguineus and found that own- ers of tick-infested dogs were 3.2 times more likely to have removed ticks from themselves (Trapp et al. 2006). Considering that $78 \%$ of the sick dogs evaluated in this study were infected with E. canis, there is a potentially significant risk of human E. canis infections transmitted by $R$. sanguineus in urban areas of southeastern Brazil. Although human E. canis cases have not been identified in Brazil, evidence of human ehrlichiosis has been reported in Brazil and other Central and South American countries, based on serology using E. chaffeensis as the test antigen (Calic et al. 2004, Perez et al. 2006). Serologically, individuals infected with E. canis or E. chaffeensis develop strong cross-reactive antibody responses (Rikihisa et al. 1994). Therefore, other authors have suggested that $E$. $c a-$ nis, rather than E. chaffeensis, infections have occurred in febrile, Ehrlichia seroreactive patients in South America (Perez et al. 2006). Our study would support this contention, at least in southern Brazil. Other Ehrlichia species were not detected in any dog. Based on 16S rRNA gene sequencing, one E. canis strain in this study had an identical sequence when compared to the E. canis strain associated with monocytic ehrlichiosis in asymptomatic and febrile human patients in Venezuela. Despite a low level of polymorphism, the 16S rRNA gene 
is considered the best current target for distinguishing various E. canis strains (Unver et al. 2001). Due to the large urban dog population, the infrequent use of acaracides, and the high prevalence of active, chronic infection in the sick dog population, and presumably a portion of the healthy dog population, E. canis may ultimately be related to human cases of fever of unknown origin, which are a frequent occurrence in Brazil and other tropical and subtropical regions (da Costa et al. 2006).

We did not find $A$. phagocytophilum or $E$. ewingii DNA in any sample. Furthermore, these organisms have not yet been detected in dogs or humans from Brazil. One possible explanation is that main tick vectors, Ixodes scapularis and Amblyomma americanum, respectively, are not present in Brazil, although other Ixodes and Amblyomma species are frequently found in rural areas (Figueiredo et al. 1999). Seroreactivity to $E$. chaffeensis has been reported in Brazilian patients (Calic et al. 2004, da Costa et al. 2006); however, no South American isolates have been reported, and molecular confirmation of E. chaffeensis or E. ewingii infection in humans has not been described. In North America, both E. chaffeensis and E. ewingii have been detected from the blood of sick dogs and human patients (Breitschwerdt et al. 1998, Buller et al. 1999, Kordick et al. 1999). Failure to amplify either of these organisms from dog blood samples in this study could reflect collection bias, including the predominance of samples from urban rather than rural dogs.

Rickettsia rickettsii can cause a very similar disease in dogs and human beings (Duncan et al. 2004). Brazilian spotted fever (BSF) is endemic in many regions of Brazil. Since 1985, 238 human cases of Brazilian spotted fever, including 88 fatalities, have been reported from 44 cities located in São Paulo state by the Center of Epidemiologic Surveillance (Secretaria da Saúde do Estado de São Paulo 2007). In one of these areas (Pedreira), canine $R$. rickettsii seroprevalence was 31\% (5/16 dogs tested) (Sangioni et al. 2005). This BSF endemic area is located $165 \mathrm{~km}$ [102.5 miles] east of the VTH, and no dogs from that region were included in our study (Fig. 1). Considering that neither R. rickettsii antibodies nor DNA was found in the larger number of cities and dogs enrolled in this study, human $R$. rickettsii exposure is presumably infrequent in these urban centers. This conclusion is further supported by the absence of $R$. rickettsii in 1,783 Amblyomma ticks collected from urban parks in a BSF endemic area (Estrada et al. 2006). Our data suggest that $R$. sanguineus is not responsible for transmission of BSF in cities in southeastern Brazil; however, $R$. sanguineus was recently found to transmit $R$. rickettsii in the southwestern United States (Demma et al. 2005).

Zoonotic visceral leishmaniasis (ZVL), caused by Leishmania chagasi (Leishmania infantum), is an endemic disease in dogs and humans in Brazil. L. chagasi antibodies were found in only two dogs $(1 \%)$. The canine seroprevalence in Leishmania endemic areas varies from $4 \%$ to $27 \%$ (Coutinho et al. 1985, Ashford et al. 1998). From 1990 to 1997, 176,000 L. chagasi seropositive dogs were detected (Ashford et al. 1998). In humans, according to the Brazilian National Human Health Surveillance Database, between 2001 and 2006, 17,951 human cases of visceral leishmaniasis were confirmed, with an average of 3,000 new cases per year. From São Paulo state, 824 human cases were reported during the same time period, with at least 74 fatalities (Ministério da Saúde do Brasil 2007). A endemic Leishmania focus is well establish in the western region of São Paulo state, where $50 \%$ of the clinically ill dogs are L. chagasi seroreactive (Moreira et al. 2002), whereas Leishmania non-endemic areas have an extremely low canine seroprevalence of $0.6 \%$ (Savani et al. 2003). From the 198 selected dogs in this study, only four were from known endemic regions, which could represent a bias toward negative serology test results. Moreover, the sandfly vector, Lutzomyia longipalpis, has not been detected in the Botucatu region, most likely because weather conditions are not optimal for its multiplication. Interestingly, a recent experimental transmission study using hamsters demonstrated that $R$. sanguineus can be a competent vector for $L$. chagasi transmission, raising the possibility that this tick could potentially contribute to the epidemiology of ZVL in some regions of Brazil (Coutinho et al. 2005).

Based on sampling of sick dogs with extensive tick exposure histories, Bartonella seroprevalence and active infection were surpris- 
ingly low in São Paulo state. In contrast to the findings in this study, 25 of 27 sick dogs (93\%) from a heavily tick-exposed (including a high infestation of $R$. sanguineus) kennel in North Carolina (USA) were infected with $B$. vinsonii berkhoffii (Kordick et al. 1999). Although no human illness was attributed to bartonellosis, eight of 23 people ( $35 \%$ ) from the kennel location were $B$. henselae seroreactive. In Brazil, human bartonellosis cases have been reported, and the seroprevalence of $B$. henselae among 437 rural inhabitants was $13.7 \%$ (da Costa et al. 2005). The distribution of Bartonella seroreactive dogs in our study suggests that urban dog populations are infrequently exposed to these pathogens. It has been hypothesized that $R$. sanguineus ticks play a role in the transmission of B. vinsonii berkhoffii to dogs (Kordick et al. 1999, Breitschwerdt et al. 2000). If true, R. sanguineus ticks in Brazil appear to be infrequently infected with $B$. vinsonii berkhoffii as compared to infection with $E$. canis.

Despite a possible population bias caused by inclusion criteria that selected for dogs infected by tick-borne organisms or variation in the number of dogs enrolled from various regional cities, the results reported in this study demonstrate good agreement between serological testing and PCR results. For those vector-borne organisms in which both serology and PCR results indicated a very low risk of exposure, peculiarities related to the geographic location of sample collection were most likely responsible for the negative test results. Because the study population represented a subset of sick dogs, prevalences obtained in this study cannot be extrapolated to the regional canine or human population. As there can be variation in the transmission patterns of many vector-borne organisms within relatively small geographic distances, these results also cannot be generalized to other regions of Brazil or other countries in South America. Active epidemiologic surveys are necessary to determine the calculated risk of human exposure to specific pathogens in tick endemic areas.

In conclusion, using dogs as a means of surveillance for selected vector-borne anthropozoonosis in southeastern Brazil indicates that human beings residing in urban areas are frequently exposed to E. canis, which has twice been reported as a human pathogen in Venezuela. Depending on the region within São Paulo state, Bartonella spp and Leishmania chagasi also pose a human health hazard. The risk of human infection with $A$. phagocytophilum, $B$. burgdorferi, E. chaffeensis, and E. ewingii appears to be low in this region of Brazil. In addition to providing a rationale and a cost-effective means of ongoing surveillance, increased coordination of public health communications among physicians and veterinarians might also decrease the risk associated with the introduction of new vector-borne pathogens from endemic regions or from other countries.

\section{ACKNOWLEDGMENTS}

The authors are grateful to Ms. Julie M. Bradley for the serological testing at North Carolina State University (NCSU); Dr. Rosangela Z. Machado and Ms. Tricia M.F.S. Oliveira from São Paulo State University (FCAV-Unesp-Jaboticabal) for Leishmania serology; Dr. João Pessoa Araújo Júnior from Biosciences Institute (IBBUnesp-Botucatu) for PCR support; Dr. Cláudio Mattoso for providing important data for this study; Tonya Lee for editorial assistance; and the staff of the College of Veterinary Medicine and Animal Science (FMVZ-Unesp-Botucatu) who contributed to the case selection and sample collection. This study was supported in part by the State of North Carolina and grants from the Brazilian foundations Fundação de Amparo à Pesquisa do Estado de São Paulo (FAPESP grant numbers 02/11117-1, 03/02627-9 and 04/093132) and Coordenação de Aperfeiçoamento de Pessoal de Nível Superior (CAPES), from the Waltham ${ }^{\circledR}$ Foundation (grant number 20060255) and IDEXX ${ }^{\circledR}$ Laboratories.

\section{REFERENCES}

Altschul, SF, Gish, W, Miller, W, Myers, EW, et al. Basic local alignment search tool. J Mol Biol 1990; 215: 403-410.

Ashford, DA, David, JR, Freire, M, David, R, et al. Studies on control of visceral leishmaniasis: impact of dog control on canine and human visceral leishmaniasis in Jacobina, Bahia, Brazil. Am J Trop Med Hyg 1998; 59: 53-57. 
Backer, LC, Grindem, CB, Corbett, WT, Cullins, L, et al. Pet dogs as sentinels for environmental contamination. Sci Total Environ 2001; 274:161-169.

Birkenheuer, AJ, Levy, MG, Breitschwerdt, EB. Development and evaluation of a seminested PCR for detection and differentiation of Babesia gibsoni (Asian genotype) and B. canis DNA in canine blood samples. J Clin Microbiol 2003; 41:4172-4177.

Bögel, K. Guidelines for Dog Rabies Control. Geneva: World Health Organization, 1987.

Breitschwerdt, EB, Hegarty, BC, Hancock, SI. Sequential evaluation of dogs naturally infected with Ehrlichia canis, Ehrlichia chaffeensis, Ehrlichia equi, Ehrlichia ewingii, or Bartonella vinsonii. J Clin Microbiol 1998; 36:26452651.

Breitschwerdt, EB, Kordick, DL. Bartonella infection in animals: carriership, reservoir potential, pathogenicity, and zoonotic potential for human infection. Clin Microbiol Rev 2000; 13:428-438.

Buller, RS, Arens, M, Hmiel, SP, Paddock, CD, et al. Ehrlichia ewingii, a newly recognized agent of human ehrlichiosis. N Engl J Med 1999; 341:148-155.

Calic, SB, Galvão, MAM, Bacellar, F, Rocha, CMBM, et al. Human ehrlichioses in Brazil: first suspect cases. Braz J Infect Dis 2004; 8:259-262.

Cleaveland, S, Meslin, FX, Breiman, R. Dogs can play useful role as sentinel hosts for disease. Nature 2006; 440: 605.

Coutinho, MT, Bueno, LL, Sterzik, A, Fujiwara, RT, et al. Participation of Rhipicephalus sanguineus (Acari: Ixodidae) in the epidemiology of canine visceral leishmaniasis. Vet Parasitol 2005; 128:149-155.

Coutinho, SG, Nunes, MP, Marzochi, MC, Tramontano, N. A survey for American cutaneous and visceral leishmaniasis among 1,342 dogs from areas in Rio de Janeiro (Brazil) where the human diseases occur. Mem Inst Oswaldo Cruz 1985; 80:17-22.

Cunha, AR, Martins, D. Comparative study among meteorological elements obtained in conventional and automated meteorological stations in Botucatu, SP, Brazil. Rev Bras Agrometeorol 2004; 12:103-111.

da Costa, PS, Brigatte, ME, Greco, DB. Antibodies to Rickettsia rickettsii, Rickettsia typhi, Coxiella burnetii, Bartonella henselae, Bartonella quintana, and Ehrlichia chaffeensis among healthy population in Minas Gerais, Brazil. Mem Inst Oswaldo Cruz 2005; 100:853-859.

da Costa, PS, Valle, LM, Brigatte, ME, Greco, DB. More about human monocytotropic ehrlichiosis in Brazil: serological evidence of nine new cases. Braz J Infect Dis 2006; 10:7-10.

Dantas-Torres, F, Figueredo, LA, Brandao-Filho, SP. Rhipicephalus sanguineus (Acari: Ixodidae), the brown dog tick, parasitizing humans in Brazil. Rev Soc Bras Med Trop 2006; 39:64-67.

Demma, LJ, Traeger, MS, Nicholson, WL, Paddock, CD, et al. Rocky Mountain Spotted Fever from an unexpected tick vector in Arizona. N Engl J Med 2005; 353: 587-594.

Dias, RA, Garcia Rde, C, Silva, DF, Amaku, M, et al. Estimate of the owned canine and feline populations in urban area in Brazil. Rev Saude Publica 2004; 38:565570.

Diniz, PPVP, Maggi, RG, Schwartz, DS, Cadenas, MB, et al. Canine bartonellosis: serological and molecular prevalence in Brazil and evidence of co-infection with Bartonella henselae and Bartonella vinsonii subsp. berkhoffii. Vet Res 2007; 38:697-710.

Duncan, AW, Correa, MT, Levine, JF, Breitschwerdt, EB. The dog as a sentinel for human infection: prevalence of Borrelia burgdorferi C6 antibodies in dogs from southeastern and mid-Atlantic states. Vector-Borne Zoonotic Dis 2004; 4:221-229.

Estrada, DA, Schumaker, TT, Souza, CE, Rodrigues Neto, EJ, et al. Rickettsiae detection in Amblyomma ticks (Acari: Ixodidae) collected in the urban area of Campinas City, SP. Rev Soc Bras Med Trop 2006; 39:68-71.

Figueiredo, LT, Badra, SJ, Pereira, LE, Szabo, MP. Report on ticks collected in the Southeast and Mid-West regions of Brazil: analyzing the potential transmission of tick-borne pathogens to man. Rev Soc Bras Med Trop 1999; 32:613-619.

Horta, MC, Labruna, MB, Sangioni, LA, Vianna, MC, et al. Prevalence of antibodies to spotted fever group rickettsiae in humans and domestic animals in a Brazilian spotted fever-endemic area in the state of Sao Paulo, Brazil: serologic evidence for infection by Rickettsia rickettsii and another spotted fever group Rickettsia. Am J Trop Med Hyg 2004; 71:93-97.

Kordick, SK, Breitschwerdt, EB, Hegarty, BC, Southwick, $\mathrm{KL}$, et al. Coinfection with multiple tick-borne pathogens in a Walker Hound kennel in North Carolina. J Clin Microbiol 1999; 37:2631-2638.

Lindenmayer, JM, Marshall, D, Onderdonk, AB. Dogs as sentinels for Lyme disease in Massachusetts. Am J Public Health 1991; 81:1448-1455.

Maggi, RG, Breitschwerdt, EB. Potential limitations of the 16S-23S rRNA intergenic region for molecular detection of Bartonella species. J Clin Microbiol 2005; 43:11711176.

Ministério da Saúde do Brasil. Sistema de Informação de Agravos de Notificação (Sinan) http://dtr2004saudegovbr/sinanweb 2007 (in Portuguese).

Moreira, MAB, Luvizotto, MCR, Nunes, CM, Silva, TCC, et al. Aplicação da técnica de imunofluorescência direta para o diagnóstico da leishmaniose visceral canina em aspirado de linfonodo. Braz J Vet Res Anim Sci 2002; 39:103-106 (in Portuguese).

Oliveira, TMFS. Antibodies anti-Leishmania chagasi in serum samples of dogs from the city of Jaboticabal-SP, Brazil, A non-endemic range of the disease. Jaboticabal: São Paulo State University (Unesp); 2004 (in Portuguese).

Perez, M, Bodor, M, Zhang, C, Xiong, Q, et al. Human infection with Ehrlichia canis accompanied by clinical signs in Venezuela. Ann N Y Acad Sci 2006; 1078:110117.

Perez, M, Rikihisa, Y, Wen, B. Ehrlichia canis-like agent isolated from a man in Venezuela: antigenic and genetic characterization. J Clin Microbiol 1996; 34:21332139. 
Rabinowitz, P, Gordon, Z, Chudnov, D, Wilcox, M, et al. Animals as sentinels of bioterrorism agents. Emerg Infect Dis 2006; 12:647-652.

Rikihisa, Y, Ewing, SA, Fox, JC. Western immunoblot analysis of Ehrlichia chaffeensis, E. canis, or E. ewingii infections in dogs and humans. J Clin Microbiol 1994; 32:2107-2112.

Sangioni, LA, Horta, MC, Vianna, MC, Gennari, SM, et al. Rickettsial infection in animals and Brazilian spotted fever endemicity. Emerg Infect Dis 2005; 11:265-270.

Savani, ES, Schimonsky BvB, Camargo, MC, D'Auria S, R. Surveillance of American visceral leishmaniasis in dogs from a non-endemic area, Brazil. Rev Saude Publica 2003; 37:260-262.

Secretaria da Saüde do Estado de São Paulo. Centro de Vigilância Epidemiológica "Prof. Alexandre Vranjac." http://www.cve.saude.sp.gov.br; 2007 (in Portuguese).

Solano-Gallego, L, Hegarty, B, Espada, Y, Llull, J, et al. Serological and molecular evidence of exposure to arthropod-borne organisms in cats from northeastern Spain. Vet Microbiol 2006; 118:274-277.

Solano-Gallego, L, Kidd, L, Trotta, M, Di Marco, M, et al. Febrile illness associated with Rickettsia conorii infec- tion in dogs from Sicily. Emerg Infect Dis 2006; 12: 1985-1988.

Taylor, LH, Latham, SM, Woolhouse, ME. Risk factors for human disease emergence. Philos Trans R Soc Lond B Biol Sci 2001; 356:983-989.

Trapp, SM, Dagnone, AS, Vidotto, O, Freire, RL, et al. Seroepidemiology of canine babesiosis and ehrlichiosis in a hospital population. Vet Parasitol 2006; 140:223-230.

Unver, A, Perez, M, Orellana, N, Huang, H, et al. Molecular and antigenic comparison of Ehrlichia canis isolates from dogs, ticks, and a human in Venezuela. J Clin Microbiol 2001; 39:2788-2793.

Address reprint requests to: Dr. Edward B. Breitschwerdt Department of Clinical Sciences College of Veterinary Medicine North Carolina State University 4700 Hillsborough Street Raleigh, NC 27606

E-mail: Ed_Breitschwerdt@ncsu.edu 
